\title{
MENGHADAPI PERSAINGAN PENYELENGGARA IBADAH HAJI KHUSUS (PIHK) DAN PENYELENGGARA PERJALANAN IBADAH UMRAH (PPIU) DI KALIMANTAN SELATAN MELALUI STRATEGI SIKLUS HIDUP PRODUK
}

\author{
Devi Noviyanti \\ Fakultas Dakwah dan Ilmu Komunikasi, UIN Antasari, Banjarmasin, Indonesia \\ Email: devianwar87@gmail.com
}

\begin{abstract}
As country with majority population of Muslims, Indonesia has provided a great opportunity for Organizers of the Special Hajj Worship (Penyelenggara Ibadah Haji Khusus-PIHK) and Organizers of the Umrah Worship Tour (Penyelenggara Perjalanan Ibadah Umrah-PPIU) to serve the people that want to departing the Hajj in a faster time. This opportunity because of the high interest of the Indonesian people to perform the Hajj worship, which has led to the long waiting of period for the Hajj worship through the regular Hajj. The province of South Kalimantan, which is the one of province with the third longest regular hajj waiting period time, provides extensive potential for PIHK and PPIU to carry out activities in order to provide services for special hajj and umrah. Therefore, it is important to do various strategies by PIHK and PPIU in South Kalimantan in the face of competition, one of them is through the product life cycle strategy (product life cycle).
\end{abstract}

KEYWORDS PIHK; PPIU; Product Life Circle

\section{Pendahuluan}

Indonesia merupakan negara yang mayoritas penduduknya beragama Islam. Menurut hasil sensus penduduk Indonesia pada tahun 2010, sebanyak 87,18\% dari 237.641.326 penduduk Indonesia adalah pemeluk agama Islam.(Wikipedia.org) Oleh karena itu, dengan banyaknya penganut agama Islam ini mengakibatkan tingginya minat haji dan umrah dari Indonesia. Hal ini selanjutnya berdampak pada lamanya waiting list bagi haji regular.

Berdasarkan data resmi dari Kementerian Agama Republik Indonesia tentang daftar tunggu haji regular untuk tahun 2019, provinsi Sulawesi Selatan merupakan provinsi dengan waiting list terlama, yakni 39 tahun dan kemudian disusul oleh Sulawesi Barat yakni 30 tahun. Sedangkan Kalimantan Selatan merupakan provinsi dengan waiting list terlama ketiga dengan waktu tunggu selama 29 tahun.(nasional.kompas.com) Adapun provinsi yang masa tunggunya tersingkat adalah provinsi Sulawesi Utara, dengan waktu tunggu 11 tahun. Waiting 
list yang sangat lama bagi haji regular memberikan permasalahan baru bagi Indonesia terkait pelaksanaan ibadah haji.

Permasalahan waiting list untuk haji regular di Indonesia berpotensi untuk menimbulkan beberapa hal, antara lain pemikiran apakah nanti pada waktu keberangkatan calon Jemaah masih hidup atau sudah meninggal dunia, masih kuat secara fisik atau sudah lemah. Misalnya seseorang yang berusia 45 tahun mendaftar pada tahun 2019 dengan waktu tunggu 29 tahun untuk daerah Kalimantan Selatan, maka perkiraan keberangkatan menunaikan ibadah haji pada usia 74 tahun. Hal lain yang muncul akibat dari waiting list yang lama ini adalah banyaknya masyarakat yang mencoba mencari alternatif lain yang bisa secara lebih cepat bisa memberangkatkan mereka ke Tanah Suci untuk melaksanakan ibadah haji. Alternatif yang sering dipakai adalah dengan menggunakan layanan haji khusus oleh Penyelenggara Ibadah Haji Khusus (PIHK). Namun tidak sedikit masyarakat yang tertipu oleh beberapa oknum PIHK yang ternyata tidak terdaftar secara resmi di Kementerian Agama. Oleh karena itu, untuk menyikapi permasalahan yang terjadi ini mengharuskan pemerintah untuk menawarkan solusi agar tidak berujung pada kegelisahan di masyarakat muslim.

Waiting list yang lama untuk haji regular Indonesia ini akhirnya berpotensi bisnis yang menjanjikan bagi pihak swasta untuk menyediakan dan melayani masyarakat melalui produk haji khusus dan umrah. Hal ini kemudian dijadikan solusi oleh Kementerian Agama untuk menyelesaikan permasalahan terkait waiting list haji regular, yakni melakukan kerjasama dengan pihak swasta, Penyelenggara Ibadah Haji Khusus (PIHK) dan Penyelenggara Perjalanan Ibadah Umrah (PPIU) untuk melayani masyarakat yang ingin menjalankan ibadah haji dan umrah. Hal ini kemudian memberikan kembali peluang bagi pihak swasta untuk saling bersaing menawarkan produk jasa dalam haji khusus dan umrah.

Hadirnya travel haji dan umrah sebagai Penyelenggara Ibadah Haji Khusus (PIHK) di Indonesia menjadi solusi bagi masyarakat muslim untuk menyelenggarakan ibadah haji dalam waktu yang lebih cepat meskipun dengan biaya yang lebih mahal. Begitu pula dengan kehadiran produk umrah oleh Penyelenggara Perjalanan Ibadah Umrah (PPIU) semakin menyempurnakan kemudahan masyarakat muslim dalam melakukan ibadah untuk menuju baitullah yang bisa lebih sering dilakukan, Oleh sebab itu, perlu disadari oleh travel haji dan umrah untuk senantiasa memperhatikan berbagai strategi dalam melakukan kegiatan pelayanan secara layak bagi berbagai pihak. Salah satu strategi yang terkait adalah strategi pemasaran. Salah satu strategi pemasaran yang harus senantiasa diperhatikan oleh PIHK dan PPIU adalah posisi PIHK dan PPIU di pasar dan strategi apa yang perlu dijalankan berkaitan dengan siklus hidupnya.

Berdasarkan data dari website resmi Kementrian Agama Provinsi Kalimantan Selatan, pada tahun 2015 tercatat secara resmi sejumlah PIHK dan PPIU yakni sebanyak 32 buah.(kalsel.kemenag.go.id) Jumlah PIHK dan PPIU di Kalimantan Selatan ini kemudian terus bertambah, sehingga pada tahun 2018 
Kemenag Kalsel kembali merilis sebanyak 44 PIHK dan PPIU yang resmi tercatat.(m.republika.co.id) Perkembangan jumlah PIHK dan PPIU ini sangat logis mengingat waiting list yang lama bagi calon Jemaah Kalimantan Selatan sehingga PIHK dan PPIU berpotensi sangat besar untuk melayani masyarakat yang ingin berangkat haji secara lebih cepat. Oleh karena itu, tidak salah apabila dikatakan persaingan PIHK dan PPIH di Banjarmasin, Kalimantan Selatan sangat tinggi.

Siklus hidup produk (Product Life Cycle/PLC) mendeskripsikan secara grafis riwayat penjualan sebuah produk atau kelas produk (product class) sejak pertama diperkenalkan ke pasar sampai dengan saat ditarik dari pasar. Menurut Philip Kotler (2005), secara umum, setiap produk memiliki empat fase atau tahap, yakni tahap perkenalan (introduction), tahap pertumbuhan (growth), tahap kedewasaan (maturity), dan tahap penurunan (decline). Setiap tahap dalam siklus hidup produk ini memiliki ciri dan strategi yang berbeda.

Analisis strategi siklus hidup produk ini penting diperhatikan oleh PIHK dan PPIU di Kalimantan Selatan mengingat beberapa alasan penting. Pertama, PIHK dan PPIU yang berada di pasar memiliki beberapa fase yang dialaminya sehingga antara PIHK dan PPIU yang baru muncul misalnya, tidak bisa disamakan strateginya dengan yang mengalami masa pertumbuhan, kedewasaan atau kemunduran. Kedua, dengan berdasarkan pada alasan persaingan yang sangat tinggi, maka PIHK dan PPIU harus benar-benar memahami posisinya di pasar sehingga bisa mengetahui siapa pesaing terdekatnya.

\section{Kajian Teori}

\section{Konsep Dasar Produk}

Konsep produk merupakan bentuk tawaran produsen baik tangible (barang) maupun intangible (jasa) untuk diperhatikan, diminta, dicari, dibeli, digunakan, atau dikonsumsi untuk memenuhi kebutuhan atau keinginan konsumen. Dengan demikian, konsep dasar produk adalah segala sesuatu yang bernilai dapat ditawarkan ke pasar untuk memenuhi keinginan atau kebutuhan.(Ali Hasan, 2013) Jadi, berdasarkan definisi tersebut, sesuatu yang ditawarkan ke pasar (produk) dapat berupa barang, jasa, ide, kegiatan, tempat, pengalaman, orang, informasi, property, ataupun organisasi.

Dilihat dari berbagai sudut pandang, produk bisa diklasifikasikan salah satunya berdasarkan tangibility. Menurut Philip Kotler (2005), berdasarkan tangibility ini, produk diklasifikasikan berdasarkan dua kelompok utama, yakni:

1. Barang (Goods)

2. Barang merupakan produk yang berwujud fisik, sehingga bisa dilihat, diraba/disentuh, dirasa, dipegang, disimpan, dipindahkan, dan mengalami perlakuan fisik lainnya. Ditinjau dari aspek durabilitas atau jangka waktu pemakaian, terdapat dua macam barang, yaitu:

a. Barang Tidak Tahan Lama (Nondurable Goods)

Barang tidak tahan lama adalah barang berwujud yang biasanya habis dikonsumsi dalamsatu atau beberapa kali pemakaian. Dengan 
kata lain, umur ekonomisnya dalam kondisi pemakaian normal kurang dari satu tahun. Contohnya gula, garam, sabun, pasta gigi dan shampoo.

b. Barang Tahan Lama (Durable Goods)

Barang tahan lama merupakan barang berwujud yang biasanya bisa bertahan lama dengan banyak pemakaian. Umur ekonomisnya untuk pemakaian normal adalah satu tahun atau lebih. Contohnya antara lain televisi, lemari es, mobil dan komputer.

3. Jasa (Services)

Jasa merupakan aktivitas, manfaat atau kepuasan yang ditawarkan untuk dijual.(Tjiptono dan Anastasia, 2016) Contohnya, bengkel reparasi, salon kecantikan, hotel, biro perjalanan, lembaga pendidikan, dan lain-lain. Menurut Kotler, jasa adalah setiap tindakan atau kinerja yang dapat ditawarkan satu pihak kepada pihak lain, yang pada dasarnya tidak berwujud dan tidak mengakibatkan kepemilikan apapun.(Philip Kotler, 2005) Sedangkan Lamb, Hair, dan Mc Daniel (2001) menyebutkan bahwa jasa adalah hasil dari usaha penggunaan manusia dan mesin terhadap sejumlah orang atau objek. Jasa meliputi perbuatan, suatu kinerja, atau suatu upaya yang tidak bisa diproses secara fisik.

Menurut Philip Kotler (2005), adapun karakteristik utama jasa menurut Kotler adalah sebagai berikut:

a. Tidak berwujud (Intangibility)

Karakteristik utama jasa adalah jasa tidak dapat dilihat, dirasakan, didengar, atau dicium sebelum dibeli. Untuk mengurangi ketidakpastian, pembeli akan mencari bukti mutu jasa tersebut. Mereka akan menarik kesimpulan mengenai mutu dari tempat, orang-orang, peralatan, bahkan komunikasi, symbol, dan harga yang mereka lihat. Karena itu, tugas penyedia jasa adalah "mengelola bukti tersebut", "untuk mewujudkan sesuatu yang tidak berwujud". Oleh karena itu, konsumen harus memiliki keyakinan penuh terhadap produsen penyedia jasa.

b. Tidak terpisahkan (Inseparability)

Biasanya jasa dihasilkan dan dikomunikasikan secara bersamaan. Jika seseorang memberikan jasa, penyedianya adalah bagian dari jasa itu. Karena klien tersebut juga hadir pada saat jasa dihasilkan, interaksi penyedia-klien merupakan ciri khusus pemasaran jasa.

c. Bervariasi (Variability)

Jasa sangat bervariasi karena bergantung pada siapa yang memberikannya, kapan dan dimana diberikan. Makna dari bervariasi itu sendiri adalah meskipun jasa yang dijual sama, tetapi berbeda yang menyediakan jasa tersebut, maka bisa berbeda pula hasilnya. 
d. Tidak tahan lama (Perishability)

Jasa tidak dapat disimpan. Sifat jasa yang mudah rusak (perishability) tersebut tidak akan menjadi masalah apabila tetap berjalan lancer. Jika permintaan berfluktuasi, perusahaanperusahaan jasa menghadapi masalah yang rumit.

Pada dasarnya, hampir setiap produk, baik produk berupa barang, jasa, ataupun entitas produk yang lainnya mengalami Siklus Hidup Produk (product life cycle/PLC). Namun, yang membedakan siklus hidup produk pada setiap produk adalah jangka waktunya. Artinya pada berbagai produk memiliki siklus hidup produk yang berbeda-beda. Ada produk yang mampu bertahan dalam jangka waktu yang lama di pasar, namun ada juga produk yang cepat hilang di pasaran. Oleh karena itu, sangat penting diperhatikan oleh setiap pemberi atau penyedia produk terkait strategi siklus hidup produknya.

Philip Kotler (2005) mengatakan bahwa produk memiliki siklus hidup berarti menegaskan empat hal:

1. Produk memiliki umur yang terbatas

2. Penjualan produk melalui berbagai tahap yang khas, masing-masing memberikan tantangan, peluang, dan masalah yang bebeda bagi penjualnya

3. Laba naik dan turun pada berbagai tahap yang berbeda selama siklus hidup produk

4. Produk memerlukan strategi pemasaran, keuangan, manufaktur, pembelian, dan sumber daya manusia yang berbeda dalam tiap tahap siklus hidupnya

Pada dasarnya, Siklus Hidup Produk adalah tahapan-tahapan proses perjalanan hidup suatu produk mulai dari diperkenalkannya kepada pasar (market) hingga pada akhirnya hilang dari pasaran.(Ilmumanajemenindustri.com) Siklus hidup produk mendeskripsikan secara grafis riwayat penjualan sebuah produk atau kelas produk (product class) sejak pertama diperkenalkan ke pasar sampai dengan saat ditarik dari pasar. Konsep ini didasarkan pada asumsi bahwa penjualan total dan profitabilitas sebuah produk berfluktuasi mengikuti pola-pola tertentu selama hidupnya.(Tiptono dan Anastasia, 2016)

Pada umumnya, Siklus Hidup Produk atau Product Life Cycle memiliki 4 Tahapan yaitu Perkenalan (Introduction), Pertumbuhan (Growth), Kedewasaan (Maturity), Penurunan (Decline). Berikut ini adalah penjelasan singkat mengenai keempat tahapan Siklus Hidup Produk beberapa strategi umum yang digunakan produsen dalam memasarkan produknya berdasarkan Fase atau Tahap Siklusnya.(Tiptono dan Anastasia, 2016)

\section{Perkenalan (introduction)}

Merupakan periode atau tahapan pertama dalam siklus hidup produk dimana produsen memperkenalkan produk barunya kepada pasar atau 
masyarakat umum. Pada saat ini periode pertumbuhan penjualan yang lambat saat produk itu diperkenalkan produk. Dalam tahap introduksi ini, produk baru lazimnya membutuhkan biaya besar untuk perancangan, pengembangan, pengujian, produksi, dan peluncurannya. Umumnya konsumen enggan dan sangat berhati-hati dalam mencoba sesuatu yang baru, terutama jasa baru yang sifatnya intangible dan tidak memungkinkan evaluasi atau ujicoba sebelum konsumsi. Mayoritas pasaran belum mengetahui dan belum familiar dengan produk baru bersangkutan. Ketersediaan produk kerapkali masih amat terbatas lingkupnya. Oleh karena itu, penjualan biasanya rendah dan pertumbuhannya lambat, serta terbatas pada mereka yang suka mencoba produk baru atau mereka yang meyakini akan mendapat status manfaat khusus lewat inovasi baru.

\section{Pertumbuhan (Growth)}

Merupakan periode dimana produk baru tersebut telah diuji/dicoba dan masalah-masalah yang muncul dalam tahap sebelumnya telah teratasi. Konsumen mulai menyadari manfaat produk dan menyukainya. Produk bersangkutan mulai banyak diadopsi. Karena itu, penjualan mulai meningkat pesat dan para pesaing mulai memasuki pasar yang sama. Pada periode ini terjadi peningkatan laba yang besar.

\section{Kedewasaan (Maturity)}

Merupakan periode dimana terjadi penurunan pertumbuhan penjualan karena produk itu telah diterima oleh sebagian besar calon pembeli. Jadi, meskipun penjualan mencapai titik puncak, tetapi pertumbuhan pasar melambat dan cenderungmenurun. Sebagian besar konsumen potensial telah mengadopsi dan mengkonsumsi produk/jasa bersangkutan. Di lain pihak, banyaknya jumlah pesaing dalam industry menyebabkan persaingan harga tak terelakkan. Laba stabil atau menurun karena persaingan yang meningkat. Pesaing-pesaing lemah satu demi satu mulai tersingkir.

\section{Penurunan (Decline)}

Merupakan periode saat penjualan menunjukkan arah yang menurun dan laba yang menipis. Penjuaan semakin merosot dikarenakan perubahan selera konsumen, produk substitusi mulai diterima konsumen, atau perubahan teknologi. Produk atau perusahaan yang tak sanggup bertahan akan keluar dari arena persaingan.

Berikut adalah gambar Siklus Hidup Produk (Product Life Cycle) menurut Philip Kotler 


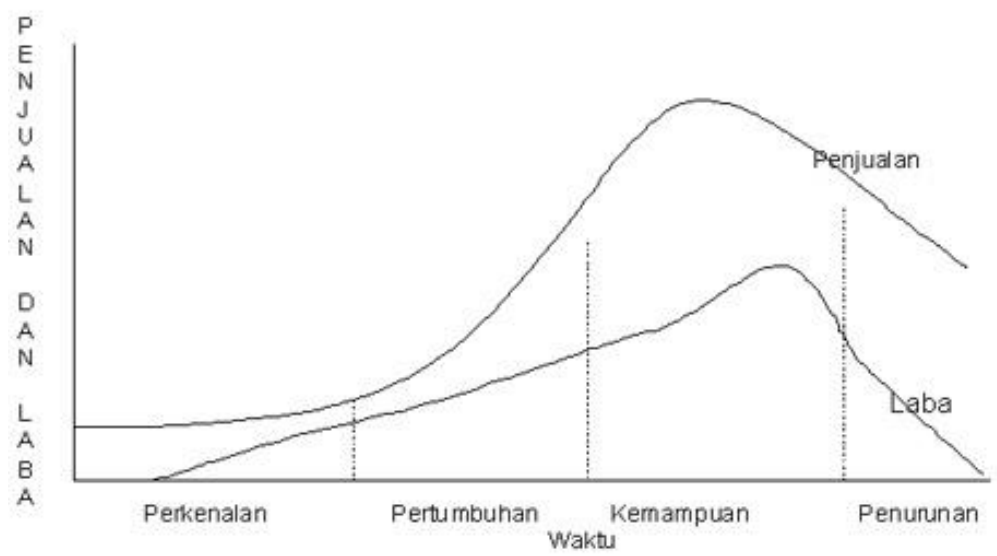

\section{Hasil Penelitian dan Pembahasan}

Strategi Siklus Hidup Produk (Product Life Cycle) Bagi Penyelenggara Ibadah Haji Khusus (PIHK) dan Penyelenggara Perjalanan Ibadah Umrah (PPIU) di

\section{Kalimantan Selatan}

Produk yang disediakan oleh PIHK dan PPIU berdasarkan golongan jenis produk tergolong produk jasa. Menurut Kotler, jasa adalah setiap tindakan atau kinerja yang dapat ditawarkan satu pihak kepada pihak lain, yang pada dasarnya tidak berwujud dan tidak mengakibatkan kepemilikan apapun.(Philip Kotler, 2005) Selain berdasarkan pada definisi tersebut, penggolongan produk PIHK dan PPIU sebagai produk jasa juga sesuai dengan ciri dari jasa, yakni tidak berwujud (Intangibility), tidak terpisahkan (inseparability), bervariasi (variability), tidak tahan lama (perishability)

Sangat penting dipahami oleh PIHK dan PPIU bahwa produk yang mereka tawarkan ke pasar memiliki fase atau siklus hidupnya. Berdasarkan pada teorinya bahwa siklus hidup produk terdiri atas Perkenalan (Introduction), Pertumbuhan (Growth), Kedewasaan (Maturity), dan Penurunan (Decline). Oleh sebab itu, perlu diketahui secara pasti kedudukan PIHK dan PPIU berada pada posisi dan tahapan yang mana, sehingga PIHK dan PPIU yang ada di Kalimantan Selatan dapat membuat strategi yang tepat dalam menghadapi persaingan yang sangat tinggi.

\section{Strategi : Tahap Perkenalan (Introduction)}

Tahapan perkenalan bagi PIHK dan PPIU merupakan tahapan pertama dalam siklus hidup produk dimana PIHK dan PPIU memperkenalkan produk barunya kepada pasar atau masyarakat umum. Adapun ciri-ciri umum tahap ini adalah penjualan yang masih rendah, persaingan yang masih relatif kecil, tingkat kegagalan relatif tinggi, masih banyak dilakukan modifikasi produk dalam pengujian dan pengembangannya (karena problem yang timbul tidak seperti yang diramalkan dan mungkin pula disebabkan pemahaman yang keliru tentang pasar), biaya produksi dan pemasaran sangat tinggi, serta distribusi yang masih terbatas. Pada tahap ini umumnya laba akan negatif atau rendah serta biaya untuk promosi 
sangat tinggi. Hal ini disebabkan karena beberapa hal, antara lain untuk menginformasikan kepada masyarakat mengenai PIHK dan PPIU yang awalnya masyarakat belum mengetahui. Sebab lain karena memerlukan usaha yang lebih untuk membujuk orang untuk memakai jasa PIHK dan PPIU yang masih belum terbukti kualitas layanannya.

Adapun strategi yang bisa dipakai untuk PIHK dan PPIU yang berada pada tahap perkenalan (introduction) ini antara lain:

1) Melakukan strategi harga dengan menggunakan strategi harga penetrasi (Penetration Pricing) atau strategi harga peluncuran (Skimming Pricing)

Strategi harga ini bisa dimanfaatkan oleh PIHK dan PPIU baru dalam memperkenalkan produk jasanya ke pasar. Strategi harga penetrasi (Penetration Pricing) atau strategi harga peluncuran (Skimming Pricing) adalah strategi harga yang ditawarkan untuk PIHK dan PPIU yang berada pada posisi perkenalan. Meskipun secara konsepnya dua jenis strategi harga ini saling bertolak belakang, namun hal ini bisa dijadikan alternatif bagi PIHK dan PPIU yang tergolong baru di pasar dan menyesuaikan dengan tujuan masing-masing perusahaan.

a. Strategi harga penetrasi (penetration pricing)

Strategi ini merupakan strategi dengan menetapkan harga relatif rendah atau murah bagi produk baru yang diperkenalkan di pasar. Harapan dari penetapan harga yang rendah ini adalah PIHK dan PPIU dapat memperoleh volume penjualan atau pangsa pasar yang besar dalam waktu relative singkat. Selain itu, dengan menggunakan stratgi harga penetrasi ini juga dapat mengurangi keinginan dan kemampuan perusahaan pesaing untuk masuk ke pasar dengan alasan harga yang murah dapat menyebabkan marjin yang diperoleh setiap perusaahan menjadi terbatas.

Strategi ini memiliki pandangan jangka panjang dengan mengorbankan laba jangka pendek untuk tercapainya keunggulan kompetitif yang berkelanjutan. Artinya, perusahaan rela mendapatkan laba sedikit atau bahkan merugi demi keuntungan yang besar di masa yang akan datang. Oleh karena itu, strategi penetration pricing ini cocok digunakan bagi PIHK dan PPIU yang ada di Kalimantan Selatan dengan bidikan pengguna yang sangat sensitive terhadap harga atau yang sangat mempertimbangkan harga.

b. Strategi harga peluncuran (skimming pricing)

Strategi ini merupakan strategi harga yang menetapkan harga yang tinggi pada suatu produk dan dilengkapi dengan gencarnya aktivitas promosi kemudian menurunkan harga tersebut pada saat persaingan mulai ketat. Metode ini akan efektif apabila konsumen tidak sensitive 
terhadap harga, namun lebih menekankan pertimbanganpertimbangan kualitas, inovasi, fitur, dan kemampuan produk bersangkutandalam memuaskan kebutuhannya. Adapun tujuan dari penerapan strategi harga skimming pricing ini menurut Agustin antara lain untuk melayani pelanggan yang tidak terlalu sensitive terhadap harga (selama belum ada persaingan); untuk menutup biaya-biaya promosi promosi yang besar; untuk membatasi permintaan hingga tingkat yang tidak melampaui kapasitas produksi perusahaan; atau bahkan untuk berjaga-jaga terhadap kemungkinan terjadinya kekeliruan dalam penetapan harga, karena akan lebih mudah untuk menurunkan harga awal yang dirasakan terlalu tinggi oleh konsumen daripada menaikkan harga awal yang terlalu murah agar dapat menutup semua biaya yang dikeluarkan.(Agustin. 2019)

Strategi skimming pricing ini akan cocok digunakan oleh PIHK dan PPIU di Kalimantan Selatan yang menyediakan produk perjalanan yang unik dan berbeda dari PIHK dan PPIU yang sudah ada. Strategi ini juga sesuai dengan PIHK dan PPIU yang memiliki target penggunanya dengan penghasilan menengah ke atas. Strategi ini dapat pula diterapkan bagi PIHK dan PPIU yang menginginkan persepsi dimasyarakat dengan interpretasi bahwa harga tinggi sebagai indikator kualitas yang tinggi pula.

2) Melakukan strategi distribusi dengan lebih fokus pada wilayah yang terbatas

Keputusan distribusi menyangkut kemudahan akses terhadap jasa bagi para penggan potensial.(Tjiptono, Fandy, 2004) Distribusi (place) dalam bauran pemasaran bisa dimanfaatkan oleh PIHK dan PPIU yang sedang berada pada tahap perkenalan. Strategi ini bisa dilakukan dengan memberikan pelayanan dengan focus pada wilayah terbatas atau tertentu saja, misalkan fokus untuk melayani masyarakat di Kota Banjarmasin saja. Hal ini dilakukan mengingat PIHK dan PPIU pada tahap perkenalan ini tergolong sangat baru sehingga masih memiliki keterbatasan dari berbagai hal, misalnya sumber daya manusia ataupun modal.

3) Melakukan strategi promosi melalui periklanan (advertising) dan penjualan individu (Personal Selling)

Media periklanan (advertising) bisa dimanfaatkan oleh PIHK dan PPIU untuk mengkomunikasi produknya kepada khalayak ramai. Periklanan merupakan salah satu komponen bauran promosi yang berarti segala bentuk presentasi nonpribadi dan promosi gagasan, barang, atau jasa oleh sponsor tertentu yang harus dibayar, entah untuk membangun preferensi merek atau untuk mendidik orang. Bagi PIHK dan PPIU di Kalimantan Selatan yang masih berada di tahap perkenalan ini dapat 
menggunakan iklan dengan tujuan memberikan informasi terkait produk jasa yang baru dihadirkan untuk melayani masyarakat. PIHK dan PPIU dapat menggunakan satau beberapa media iklan yang disesuaikan dengan kemampuan perusahaan. Misalnya memperkenalkan melalui harian surat kabar local seperti Banjarmasin Post, saluran televisi lokal seperti TVRI Kalimantan Selatan, radio lokal, atau menggunakan media baliho yang berada pada lokasi-lokasi strategis. Dengan hal ini, diharapkan masyarakat Kalimantan Selatan dapat mengetahui dan mengenal PIHK dan PPIU dengan produk baru yang siap dan bersedia melayani masyarakat Kalimantan Selatan yang ingin melakukan ibadah haji ataupun umrah.

Selain menggunakan media periklanan, PIHK dan PPIU juga dapat memperkuat promosi mereka pada tahap perkenalan ini melalui tenaga penjual/penjualan individu (personal selling). Tenaga penjual/penjualan individu (personal selling) ini dapat dikatakan sebagai media promosi yang paling lengkap karena masyarakat sebagai calon konsumen dapat menanyakan apapun yang masih belum dipahami dan diketahui kepada tenaga penjual ini. Oleh karena itu, PIHK dan PPIU harus benar-benar membekali dengan hal-hal yang dapat mendukung tenaga penjual agar pada saat mereka menyampaikan informasi ke masyarakat Kalimantan Selatan, mereka dengan penyampaian yang benar dan tepat, sehingga mereka mampu meyakinkan masyarakat. Misalnya dengan peningkatan skill komunikasi yang baik dan meningkatkan pengetahuan mengenai produk.

\section{Tahap Pertumbuhan (Growth)}

Tahap pertumbuhan (Growth) bagi PIHK dan PPIU di Kalimantan Selatan adalah tahap dimana produk yang diperkenalkan sudah dikenal dan diterima oleh masyarakat Kalimantan Selatan sebagai pengguna produk jasa mereka. Beberapa ciri-ciri pada tahap pertumbuhan ini antara lain penjualan yang semakin meningkat dan diikuti oleh kenaikan laba; tingkat pertumbuhan pasar yang tinggi; dan jumlah pesaing yang semakin banyak.

Adapun strategi yang bisa digunakan oleh PIHK dan PPIU pada tahap ini antara lain sebagai berikut:

1) Menurunkan harga, menetapkan harga setara, atau lebih murah dibandingkan pesaing

Strategi ini bisa dilakukan oleh PIHK dan PPIU untuk menarik lapisan berikutnya yang terdiri dari pembeli yang sensitive terhadap harga. Melalui penurunan harga, penetapan harga setara, atau bahkan lebih murah daripada pesaing ini diharapkan akan mampu mengajak masyarakat yang awalnya sangat peka terhadap perbedaan harga dapat 
menghilangkan perasaan tersebut dan pada akhirnya bersedia untuk memutuskan menggunakan produk ini.

\section{2) Meningkatkan mutu produk}

Mutu produk yang dimaksud disini bisa kita lihat dari sisi kualitas jasa PIHK dan PPIU itu sendiri sebagai penyedia jasa. Berdasarkan pada pengetahuan yang ada bahwa jasa itu pada dasarnya tidak berwujud, tetapi hanya bisa dirasa dan dilihat buktinya saja. Maka sangat wajar apabila masyarakat menilai kualitas jasa berdasarkan unsur-unsur pembentuknya. Dalam Kotler dan Killer disebutkan bahwa kualitas jasa ditentukan oleh beberapa hal, yakni : keandalan (kemampuan melaksanakan layanan yang dijanjikan secara meyakinkan dan akurat); daya tanggap (kesediaan membantu pelanggan dan memberikan jasa dengan cepat); jaminan (pengetahuan, kesopanan karyawan dan kemampuan menyampaikan kepercayaan dan keyakinan); empati (kesediaan memberikan perhatian yang mendalam dan khusus kepada masing-masing pelanggan); serta bukti fisik (penampilan fasilitas fisik, perlengkapan, karyawan, dan bahan komunikasi). ${ }^{1}$ Kelima faktor penentu kualitas jasa ini atau yang biasa disebut dengan service quality dapat dijadikan acuan oleh PIHK dan PPIU sebagai bentuk upaya untuk meningkatkan mutu produk.

\section{3) Memasuki segmen pasar yang baru}

Strategi ini bisa dijadikan langkah selanjutnya bagi PIHK dan PPIU untuk terus tumbuh dan bersaing sebagai penyedia jasa ibadah haji dan umrah. Menambah segmen berarti selanjutnya akan menambah target pasar/bidikan konsumennya. Misalnya, pada tahap perkenalan, segmen berdasarkan pada pendapatan (misal tersedia paket ekonomis dan paket gold untuk menengah ke atas), maka pada tahap pertumbuhan ini PIHK dan PPIU menambah bidikan konsumennya berdasarkan pada gaya hidup. Sehingga disediakan produk yang bisa dipilih oleh masyarakat konsumennya sesuai dengan gaya hidup mereka, misalnya yang suka dengan wisata, maka tersedia pula paket kunjungan negara wisata lainnya, selain ke Tanah Suci.

\section{4) Iklan yang lebih agresif}

Strategi ini dilakukan agar konsumen tidak lagi hanya menyadari dan mengetahui tentang produk perusahaan, tetapi beralih untuk memilih dan memutuskan menggunakan jasa dari PIHK dan PPIU yang bersangkutan.

\section{5) Meningkatkan cakupan distribusi}

${ }^{1}$ Kotler dan Killer. 2007. Manajemen Pemasaran. 
Meningkatkan cakupan distribusi bisa dilakukan oleh PIHK dan PPIU yang berada pada tahap pertumbuhan ini misalnya melalui pembukaan cabang baru atau memperluas wilayah jangkauan layanan.

\section{Strategi : Tahap Kedewasaan (Maturity)}

Tahap kedewasaan merupakan tahap siklus hidup produk dimana tingkat pertumbuhan produk mereka melambat, bersaing dengan ketat dan berjuang dalam merebut pangsa pasar dengan pesaing-pesaingnya. Kotler menyebutkan tahap kedewasaan ini dapat dibagi menjadi tiga fase, yakni kedewasaan bertumbuh, stabil, dan menurun.(Philip Kotler, 2005) Ini artinya bahwa ketika sampai pada titik puncak siklus ini, perusahaan dapat mengalami tiga hal yang akan dihadapi selanjutnya, yakni terus tumbuh, bertahan dengan keadaan yang sama pada kondisi saat ini, atau malah turun dari keadaan yang sekarang. Oleh karena itu, PIHK dan PPIU yang ada di Kalimantan Selatan perlu menyadari dan membuat strategi yang tepat pada fase ini untuk menghadapi persaingan yang tinggi.

Adapun strategi yang ditawarkan bagi PIHK dan PPIU pada tahap kedewasaan ini adalah sebagi berikut:

1) Memperbaiki, memodifikasi, memperbanyak pilihan produk

Strategi ini diharapkan menjaga agar PIHK dan PPIU berada pada posisi stabil dan bahkan terus bertumbuh. Usaha untuk terus memperbaiki kualitas layanan jasa diharapkan akan mampu menjaga dan meningkatkan kepuasan konsumen yang menggunakan jasa sehingga tidak ada alasan bagi mereka untuk beralih menggunakan jasa pesaing. Selain itu, usaha untuk memodifikasi dan memperbanyak pilihan produk adalah bukti perusahaan melakukan inovasi untuk terus berusaha memenuhi kebutuhan dan keinginan msyarakat Kalimantan Selatan sebagai pengguna jasa mereka.

\section{2) Meninggalkan varian produk yang tidak kuat di pasar}

Varian produk PIHK dan PPIU yang tidak kuat di pasar harus ditinggalkan karena bisa menyebabkan kerugian bagi perusahaan. Varian ini bisa diketahui oleh perusahaan dengan menganalisis hasil penjualan yang rendah. Varian yang tidak kuat ini dapat disebabkan oleh berbagai hal yang mungkin saja tidak sesuai dengan keinginan dan kebutuhan pasar sehingga tidak dipilih oleh konsumen.

\section{3) Menerapkan harga yang lebih bersaing}

Penerapan strategi ini bisa dilakukan oleh PIHK dan PPIU misalnya dengan cara menurunkan harga; atau memberikan harga yang pantas dan terbaik dengan produk jasa yang diberikan sehingga mampu bersaing dengan produk dari pesaingnya. 


\section{4) Menggunakan iklan yang persuasif agar mempengaruhi konsumen untuk menggunakan produknya.}

Iklan sebagai media promosi tetap harus dipertahankan pelaksanaannya agar tetap terjaga kedudukan produk di dalam ingatan konsumen. Tujuan iklan yang pada mulanya lebih bersifat pemberi informasi, harus diubah strateginya menuju sebuah ajakan (persuasive) untuk menggunakan produk jasa dari PIHK dan PPIU yang bersangkutan.

\section{Strategi : Tahap Penurunan (Decline)}

Tahap penurunan merupakan tahap akhir dalam siklus hidup produk. PIHK dan PPIU dapat dikatan mengalami tahap ini ketika mereka menghadapi penurunan laba secara signifikan karena penjualan yang merosot. Kemerosotan penjualan ini bisa disebabkan oleh berbagai faktor, antara lain kemajuan teknologi, pergeseran selera konsumen, atau meningkatnya persaingan.

Pada tahap ini, PIHK dan PPIU dapat mengadopsi strategi yang ditawarkan oleh Kathryn Harrigan dalam Kotler (2005) berikut:

1) Meningkatkan investasi perusahaan untuk mendominasi atau memperkuat posisi persaingannya;

2) Mempertahankan level investasi perusahaan sampai ketidakpastian tentang industry itu terselesaikan;

3) Mengurangi level investasi perusahaan secara selektif dengan melepas kelompok pelanggan yang tidak menguntungkan, sambil memperkuat investasi perusahaan di tempat-tempat yang menguntungkan;

4) Menuai investasi perusahaan untuk memulihkan kas secepatnya, artinya mengharuskan pengurangan produk atau biaya usaha secara bertahap sambil berusaha mempertahankan penjualannya;

5) Melepaskan bisnis itu secepatnya dengan menjual asetnya dengan cara yang paling menguntungkan.

\section{Simpulan}

Pada dasarnya, hampir setiap produk, baik produk berupa barang, jasa, ataupun entitas produk yang lainnya mengalami Siklus Hidup Produk (product life cycle/PLC). Namun, yang membedakan siklus hidup produk pada setiap produk adalah jangka waktunya. Artinya pada berbagai produk memiliki siklus hidup produk yang berbeda-beda. Adapun tahapan pada siklus hidup produk dibagi menjadi empat fase, yakni tahap perkenalan, tahap pertumbuhan, tahap kedewasaan dan tahap penurunan.

Kalimantan Selatan yang merupakan provinsi dengan waiting list haji terlama ketiga telah memberikan peluang bagi Penyelenggara Ibadah Haji Khusus (PIHK) dan Penyelenggara Perjalanan Ibadah Umrah (PPIU) untuk melayani 
masyarakat yang ingin melaksanakan haji lebih cepat dan melakukan perjalanan umrah. Apabila dikaitan dengan jenis tawaran produk, maka PIHK dan PPIU menawarkan produk berupa jasa.

Berdasarkan asumsi bahwa setiap produk yang ditawarkan oleh perusahaan mengalami siklus hidup produk, maka PIHK dan PPIU, termasuk PIHK dan PPIU Kalimantan Selatan, harus senantiasa memperhatikan strateginya terkait dengan siklus hidup untuk produk yang mereka tawarkan. Hal ini penting mengingat setiap tahap siklus hidupnya, setiap produk tidak bisa menggunakan strategi yang sama. Oleh sebab itu, perlu diketahui secara pasti kedudukan PIHK dan PPIU berada pada posisi dan tahapan yang mana, sehingga PIHK dan PPIU yang ada di Kalimantan Selatan dapat membuat strategi yang tepat. Terlebih lagi dengan jumlah PIHK dan PPIU di Kalimantan Selatan yang terus bertambah jumlahnya menyebabkan persaingan juga semakin tinggi.

\section{Referensi}

Hasan, Ali. 2013. Marketing dan Kasus-kasus Pilihan. Yogyakarta: CAPS

Kotler, Philip. 2005. Manajemen Pemasaran. Jilid 1. Terjemahan. Jakarta: Indeks.

Kotler, Philip dan Keller. 2007. Manajemen Pemasaran. Jilid 2. Terjemahan. Jakarta: Indeks. Lamb, Hair, McDaniel. 2001. Pemasaran. Buku 1. Jakarta: Salemba Empat.

Shinta, Agustina. 2019. Manajemen Pemasaran. Malang: Universitas Brawijaya Press.

Tjiptono, Fandy dan Anastasia Diana. 2016. Pemasaran Esensi dan Aplikasi. Yogyakarta: Andi.

https://id.wikipedia.org/wiki/Agama_di_Indonesia. (Tanggal Akses 4 Maret 2019)

https://nasional.kompas.com/read/2019/02/12/14250341/kemenag-rilis-lamanya-antreanhaji-indonesia-sulsel-mencapai-39-tahun. (Tanggal Akses 4 Maret 2019)

https://m.republika.co.id/berita/jurnal-haji/berita-jurnal-haji/p4redh396/emwowwaitinglist-emhaji-kalsel-27-tahun (Tanggal Akses 10 Maret 2019)

https://ilmumanajemenindustri.com/pengertian-siklus-hidup-produk-product-life-cycle/ (Tanggal Akses 7 April 2019)

www.kalsel.kemenag.go.id. (Tanggal Akses 13 Februari 2016) 